\begin{tabular}{c} 
Volume and Issues Obtainable at Center for Sustainability Research and Consultancy \\
Journal of Business and Social Review in Emerging Economies \\
ISSN: 2519-089X \& ISSN (E): 2519-0326 \\
Volume 7: Issue 3 September 2021 \\
CSRᄃ \\
Journal homepage: www.publishing.globalcsrc.org/jbsee \\
\hline
\end{tabular}

\title{
Tehrik e Taliban Pakistan (TTP) and Militancy in Pakistan
}

\author{
*Surriya Shahab, PhD Scholar, Institute of Social and Cultural Studies, Bahauddin Zakariya \\ University, Multan \\ Muhammad Idrees, Visiting Lecturer, Pakistan Studies, Bahauddin Zakariya University, Multan \\ Shaida Rasool, Visiting Lecturer, Pakistan Studies, Bahauddin Zakariya University, Multan \\ Samana Mehreen, Visiting Lecturer, Pakistan Studies, Bahauddin Zakariya University, Multan
}

*Corresponding author's email: fanibzu@gmail.com

\section{ARTICLE DETAILS \\ History}

Revised format: Aug 2021

Available Online: Sep 2021

\section{Keywords}

Peace talks,

Tehrik e Taliban Pakistan

(TTP), Agenda Setting,

Editorial Policy,

Comparative Analysis

JEL Classification

ZOO, Z29

\section{ABSTRACT}

Purpose: Negotiations between two parties always have newsworthiness. Results of the negotiations can be strongly influenced by the media coverage. Pakistan's government was also involved in peace negotiation with Tahrik e Taliban Pakistan (TTP) during January and February 2014. It was the most discussing issue in Pakistani media at that time. The aim of this research is to analyze the editorial policy of three Pakistani English language newspapers; Dawn, Nation and The News to check their favorable or unfavorable behavior regarding peace talks during January and February 2014.

Design/Methodology/Approach: Agenda setting, priming and farming theories were used in this study. Qualitative content analysis method was used in this study to analyze the editorial policy of these three newspapers.

Findings: The results revealed that all these three newspapers gave significant coverage to the peace talks issue but Nation gave more coverage to the issue. Findings also revealed that Dawn and The News, most of the time showed neutral behavior but tilted towards unfavorable position regarding peace talks. Nation showed strongly unfavorable behavior regarding peace talks.

Implications/Originality/Value: So it is concluded that all these three newspapers were mostly against the peace talks and government and media were not on the same page on the issue of peace talks.

(C) 2021 The authors, under a Creative Commons AttributionNonCommercial 4.0

Recommended citation: Shahab, S., Idrees, M., Rasool, S. and Mehreen, S. (2021). Tehrik e Taliban Pakistan (TTP) and Militancy in Pakistan. Journal of Business and Social Review in Emerging Economies, 7 (3), 513-526.

\section{Introduction}

The majority of Muslims in Pakistan is ill-informed the real and basic principles and concepts of Islamic Jihad. Due to lacks of knowledge about Jihad, the militant terrorist's organizations have easily trapped them. The youth in Pakistan come under the influence of Jihadi organizations 
easily. They portrayed that Indian-held Jammu and Kashmir (IJK) and Afghanistan had illegally occupied by no-Muslims forces and the people of Kashmir and Afghanistan are struggling for their freedom and it is our religious duty and responsibility to support them and fight against foreign forces who has occupied their home. The appearance and rising of Talibanization in Pakistan is measured a needle of Extremism. Tehreek-e-Taliban of Pakistan (TTP) in the Province of Khyber Pakhtun Khwa (KPK) and other areas of Pakistan is not an individual organization but it is an alliance of different extremists and terrorists who came from other militant and terrorist organizations. The Tehrik-i-Taliban Pakistan (TTP) is considered the biggest and fatal terrorist umbrella organization in Pakistan (Yusufzai, 2009). Most terrorist groups operating in Pakistan had merged under the Tehreek-e-Taliban Pakistan (TTP) (Yusufzai, 2008). After the United State of America and NATO invasion of Afghanistan in October, 2001, the militant of Lashar-e-Jhangvi (LeJ), Lashkar-e-Tayyabe (LeT), Jaish-e-Muhammad (JeM), Sipah-e-Sahaba Pakistan (SSP), Tehrik-e-Nifaz-e-Shariat-e-Muhammadi(TNSM), Tehrik-eIslami(TeJ), Al Qaeda (AQ), Millat-e-Islamia Pakistan(MIP), Khudam-ul-Islam(KUI), Islami Tehrik-e-Pakistan(ITP), Hizb-ul-Tahir(HUT), Jamat-ul-Ansar(JUA) and Jamat-ul-Furqan(JUF) escaped from Afghanistan and settled in the Federal Administrative Tribal Area(FATA) of Khyber Pakhtun Khwa and later on they organized themselves. Tehrik-e-Taliban Pakistan (TTP Urdu: تحريك طالبان پاكستان) is a largest umbrella organization of various radical terrorist armed groups of different organizations who fled from Afghanistan to Pakistan after the US invasion in Afghanistan (Yusufzai, 2008). Before the official formation of Tehreek-e-Taliban of Pakistan, many of its current member groups were operating and launching their operations in Pakistan independently. They reorganized themselves and motivated various militant groups and tribes to found their own Taliban-affiliated militias. The Forty militant Commanders from 13 militant groupers had gathered secretly in the Tribal areas of Khyber Pakhtun Khwa and decided to form Tehrik-e-Taliban Pakistan (TTP) on December 14, 2007(Dawn, 11Dec. 2007).

\section{Organizational Structure of Tehreek-e-Taliban of Pakistan}

Baitullah Mehsud was nominated its Ameer (Abbas, 2017). Maulana Hafiz Gul Bahadur from North Waziristan was nominated as Niab(deputy) of Baitullah Mehsud, and Maulana Faqir Mohammad of Bajaur Agency was elected as a third in command. Maulana Fazlullah was appointed the secretary-general and head of the Swat chapter of the TTP, whereas Maulvi Omar was declared the official spokesperson of Tehreek-e-Taliban of Pakistan. (Daily Times, 16 Dec. 2007). The other eminent commander of Tehrik-e-Taliban Pakistan (TTP was Sadiq Noor from South Waziristan. The senior leaderships of the militants from South Waziristan, North Waziristan, Orakzai Agency, Kurram Agency, Mohmand Agency, Bajaur and Darra Adamkhel, and the districts of Swat, Buner, Upper Dir, Lower Dir, Bannu, Lakki Marwat, Tank, Peshawar, Dera Ismail Khan, Mardan and Kohat, had participated the meeting. A Shura (Consultative Council) of forty senior Taliban leaders was constituted to guide the Tehreek-e-Taliban of Pakistan. The large numbers of the groups who had joined the Tehreek-e-Taliban of Pakistan had already confrontations with Pakistan Army and Pakistani Army believed that TTP formation is against the Army. There is no clear figure and number of the Tehreek-e-Taliban of Pakistan fighters in Pakistan; it is estimated that figures range from 5,000 to 30, 000. (Mir, 2008). The exact numbers of foreign and local fighters were not clear and were uncertain. The official figures ranged from 500 to 8,000(Daily Times, 30 Sep. 2009). In Swat, the figures go to be over 5,000(Mir, 2009).

\section{The Main and Central Goals and Objectives of TTP}

Tehreek-e-Taliban of Pakistan (TTP) had announced that there are three main goals for its establishment(Yusufzai, 2009).

1- To struggle for the enforcement of Shariah Law in Pakistan;

2- To provide a unified front organization for combating U.S.-led coalition forces in Afghanistan; 3-To start defensive jihad against Pakistani security forces 
The Tehreek-e-Taliban of Pakistan had announced that it will conduct defensive jihad against Pakistani security forces however, it had launched openly operations not only against the Pakistani Security Forces but also targeted the civilians. The main purpose of formation of Tehrik-e-Taliban Pakistan (TTP) was to create resistance against the Pakistan state. (Carlotta, Khan, Shah \& Taimoor, 2009). The leader of Tehrik-e-Taliban Pakistan (TTP) had considered that Pakistan had Supported US-led Allies forces against Al-Qaeda and Afghan Taliban and Pakistan should get the lessons and consequences of the support. The movement of Tehrik-eTaliban Pakistan (TTP) began from South Waziristan agency of Khyber Pakhtun Khwa and within a few years, it took into its orbit the tribal areas and it soon spread over the country. The extremists from various militant organizations had joined hands with Tehrik-e-Taliban Pakistan (TTP). It had started an insurgency against Pakistan and it had tried to establish a state within the state. Tehrik-e-Taliban Pakistan (TTP) had challenged the writ of state and tried to enforce its own Shariah (Rana, 2009). Tehrik-e-Nifaz-e-Shariat-e-Muhammadi in Malakand and Lal Masjid clerics and militants in Islamabad supported the activities and causes of Tehrik-e-Taliban Pakistan (TTP). They supported it to enforce of Shariah Law in Pakistan. They had completely joined hands with of Tehrik-e-Taliban Pakistan (TTP). The extremist land scape was very fertile for growth of militancy and Tehrik-e-Taliban Pakistan (TTP) had exploited it. The Tehrik-eTaliban Pakistan (TTP) had started to say the Pakistani Army is Anti-Islam because it was supporting Anti-Islam forces US and its allies. Tehrik-e-Taliban Pakistan (TTP) announced that it was its religious duty to overthrow government to establish of Taliban Government which enforce Islamic Laws basis on Quran and Sunnah (United States Department of States, 19 Jul. 2016). The organization had started terrorist attacks on Pakistani Army and 300 Pakistan's army personal were kidnaped by the Tehrik-e-Taliban Pakistan (TTP) in October, 2008. (Counter Terrorism Department Punjab Police, p.27). It was great victory of the Taliban against the Pakistan army. The armies personal were released by the Taliban in exchange of Taliban extremists from Pakistan prisons. The more than forty thousand militants had joined Tehrik-eTaliban Pakistan (TTP) and some were from Afghan Taliban and Al-Qaeda. Many small militant merged into Tehrik-e-Taliban Pakistan (TTP) who had strengthened it. Very soon, Tehrik-eTaliban Pakistan (TTP) had got the status parallel to Tribal Elders in Federal Administrative Tribal Areas(FATA). Baitullah Mehsud was killed in US drone attack on August 5, 2009(Dawn, 6 Aug. 2009). Hakeemullah Mehsud was chosen Commander of Tehrik-e-Taliban Pakistan (TTP)(The Daily Times, 10 Aug. 2009). He was killed on November 1, 2013(Dawn, 2 Nov. 2013). Khan Saeed Sajna was nominated interim commander of the Tehrik-e-Taliban Pakistan (TTP). The spokesman of Tehrik-e-Taliban Pakistan (TTP), Ehsanullah Ehsan announced that the Shoura of Tehrik-e-Taliban Pakistan (TTP) had elected Mullah Fazalullah commander of Swat Valley as Ameer of Tehrik-e-Taliban Pakistan (TTP) through secret ballet. Some groups of the Tehrik-e-Taliban Pakistan (TTP) had refused to recognize him as an Ameer of the Tehrik-eTaliban Pakistan (TTP). Khan Saeed Sajna group, OmerKhalid Khorsani and Shir Yar separated from Tehrik-e-Taliban Pakistan (TTP). Omer Khalid Khorsani had established its own organization Jamaat-ul-Ahrar. Khan Saeed Sajna was killed in a US drone strike which occurred in Kharh Tangi area of Afghanistan on February 9, 2018(Dawn, 9 Feb. 2018). In February, 2017, the various groups of Tehrik-e-Taliban Pakistan (TTP) had again reunited. Jamaat-ul-Ahrar had conducted terrorist and suicide attacks from 2014 to 2017 in Pakistan. This organization was involved in terrorist attacks in Wahga border attack Lahore, Uhanna Abad Lahore, Gulshin Park Lahore, Chairing Cross Mall Road Lahore, Fruit Market Lahore, Arfa Karim Tower Lahore and Civil Hospital Quetta. Tehrik-e-Taliban Pakistan (TTP) Tariq Afridi Group which was known as Tariq Gidar Group was actively involved into terrorist activities and suicide bombings in Pakistan. Before joining Tehrik-e-Taliban Pakistan (TTP), this was conducting terrorist activities with the collaboration of Sipah-e-Sahaba Pakistan and Lashkar-e- Jhangvi. In 2008, this group had kidnapped Poland Engineer from Attack and later killed him and uploaded his video on internet. Tariq Afridi Group. Had established its training camp in Khyber agency and after operation in Khyber Agency, the Army had destroyed his camp. Tariq Afridi was killed in 2012 
(Dawn, 15 Feb. 2013). After his killing, commander of this group was taken by omer Mansoor urf Khalifa Omer Naray. He was the master mind of attacks on Army Public School, Peshawar, Bacha Khan University Mardan. Omer Mansoor was killed on July 9, 2016 (The News International, 10 Jul. 2016). After his killing, Mofti Muhammad Iqbal who is also known with the name of Mofti Ghafran became the Ameer of Tariq Afridi Group. Maulana Fazlullah had performed his responsibility as a third Ameer of The-e-Taliban of Pakistan from 2013 to 2018 and was killed in U.S. drone strike in Kunar, Afghanistan on June 14, 2018. After the death of Maulana Fazlullah, Mufti Noor Wali Mehsud was appointed the new fourth Ameer of Tehreek-eTaliban on June 22, 2018 and he previously was fighting with the Afghan Taliban against the Northern Alliance after 9/11 events and he also served as Deputy of Baitullah Mehsud in 20022003 before the formation of Tehreek-e-Taliban of Pakistan. He belongs to Mahsud tribal and previously two Ameers of Tehreek-e-Taliban were from Mehsud tribe (Dawn, 23 Jun. 2018).

\section{Affiliated Terrorist Organization of Tehreek-e-Taliban of Pakistan}

The affiliated terrorist organizations of Tehrik-e-Taliban Pakistan (TTP) are Sipah-e-Sahaba Pakistan (SSP), Al-Qaeda (AL), Tehreek-e- Nifaz Shariat Muhammadi (TNSM) and Lashkar-eJhangvi (LeJ). Tehrik-e-Taliban Pakistan (TTP) has structural organizational units in Khyber Pakhtun Khwa, Punjab, Balochistan, Sindh and Islamabad.

\section{Terrorist Attacks of Tehreek-e-Taliban of Pakistan}

The focus of Tehreek-e-Taliban of Pakistan is to combat Pakistani security forces and the major targets of Tehrik-e-Taliban Pakistan (TTP) are Pakistani Army, Law Enforcement Agency(LEM), important government office, Public gatherings, Girls Schools, Music centers, and Shia personalities and their Imanbargahs. From its formation December, 2007, Tehrik-e-Taliban Pakistan (TTP) had involved into terrorist activities and suicide bombings. Tehreek-e-Taliban of Pakistan had conducted first attack a suicide attack on a military convoy in Mingora, Swat on December 23, 2007 (The Daily Times, 42 Dec. 2007) and killed 13 security personnel and injured 25 in the attack (Dawn, 24 Dec. 2007). The terrorists of Tehrik-e-Taliban Pakistan (TTP) attacked two-time Prime Minister Benazir Bhutto in Rawalpindi on December 27, 2007 and she was assassinated 20 other were also killed and many were injures (Dawn, 28 Dec. 2007). In January 2009, Al-Qaeda chief Osama bin Laden and Afghan Taliban leader Mullah Omar had met with the leaders of Tehreek-e-Taliban Baitullah Mehsud, Hifiz Gul Bahadur and Maulvi Nazir and emphasized the TTP leader to put away their differences and reduce their operations in Pakistan in order to help Afghan Taliban for countering U.S. collision forces in Afghanistan but Tehreek-e-Taliban Pakistan had not accepted this proposal (Harnisch, 2009). The suicide attacker of Tehrik-e-Taliban Pakistan (TTP) had targeted the gathering of the lawyers outside the Lahore High Court, Lahore on January 10, 2008 and 24 people were killed and 73 were injured (Dawn, 11 Jan. 2008). The suicide bomber of Tehrik-e-Taliban Pakistan (TTP) had blast himself at the crowd of Mirza Qasim Baig Imambargah in Peshawar on January 17, 2008 and 12 people were killed and 25 were injured (The Daily Times, 18 Jan. 2008). The Suicide bomber of Tehrik-e-Taliban Pakistan (TTP) had crashed his bike into armed force bus taking students and officials of Army Medical College Rawalpindi on February 4, 2008 and the incident had killed 10 people and injured 27 people (Dawn, 5 Feb. 2008). The Tehrik-e-Taliban Pakistan (TTP) had blast powerful explosion in an election rally in Charsadda on February 9, 2008 and killed 25 people and wounded 35 people (The Nation, 10 Feb. 2008). A suicide bomber of Tehrik-eTaliban Pakistan (TTP) attacked on a public meeting at Miranshah North Waziristan on February 11, 2008 and 8 people were killed and more than dozen were injured (The Daily Times, 12 Feb. 2008). The suicide bomber of Tehrik-e-Taliban Pakistan (TTP) had blown himself in Mingora, Swat on February 29, 2008 and 38 people were killed and 75 people were injured in the incidents of suicide(Dawn, 1 Mar. 2008). Two suicide bombers had blown themselves in the parking area of the Pakistan Navy War College, Lahore on March 4, 2008 and eight people were killed and 24 people were injured(The News International, 5 Mar. 2008). The Pakistan Naval Institution was first time targeted before this army was targeted at least eight times and Pakistan Air Force was targeted twice. The Tehrik-e-Taliban Pakistan's terrorists had targeted and attacked at the Punjab Regimental Center of Army in Mardan on May 18, 2008 and 13 people including four soldiers were killed and 20 were injured (The Daily Times, 19 May. 2008). It was second attack of the terrorist after April 25, 2008 in Mardan. The terrorists of Tehrik-e-Taliban Pakistan (TTP) had attacked a Pakistan Air Force bus carrying personnel from military base on August 12, 2008. In the 
incident, 14 people were killed and 11 were injured (Parlez, 2008). It was third attack on Pakistan Air Force. Two suicide bombers of the Tehrik-e-Taliban Pakistan (TTP) had blown themselves outside the gate of Pakistan Ordnance Factories Wah Cantonment on August 21, 2008 and 70 people were killed and 67 were injured(Bloomberg, 22 Aug. 2008). Tehrik-e-Taliban Pakistan (TTP) had exploded a bomb in Islamabad on August 26, 2008 and 8 people were killed and 20 were wounded (The Daily Times, 27 Aug. 2008). The terrorists of Tehrik-e-Taliban Pakistan (TTP) had exploded a truck bomb outside the Marriott Hotel in Islamabad on September 20, 2008 and 57 people were killed and 266 people were injured(Dawn, 21 Sep. 2008). The suicide bomber of the Tehrik-e-Taliban Pakistan (TTP) had attacked on a main Police Headquarter in Islamabad on October 9, 2008 and eight people were killed and 8 people were injured(BBC News, 9 Oct. 2008) . The suicide bomber of TTP had hit the check post in Mohmand Agency on October 26, 2008 and killed seven Frontier Corps and three Khasadars, and injured five persons(The Daily Times, 27 Oct. 2008). Tehrik-e-Taliban Pakistan (TTP) had attacked on a checkpoint in Mianwali on February 7, 2009 and seven officers were killed(BBC News, 7 Feb. 2009). A suicide bomber of TTP had killed five students and injured 12 students when he attacked on Girls Madrassah in Pishin on March2, 2009(The Daily Times, 3 Mar. 2009). A convoy carrying in two buses of Sri Lanka team was attacked by the terrorists of Tehrik-e-Taliban Pakistan (TTP) in Lahore on March 3, 2009 and six members of the Sri Lankan team were injured(Dawn, 4 Mar. 2009). A suicide bomber of TTP had blast himself near bus stand of Pirwadhai in Rawalpindi and 14 people were killed and 17 people were injured. The terrorists of TTP had attacked the police vehicle at the entrance of the University of Malakand and five people including three policemen were killed(The Daily Times, 19 Mar. 2009). A suicide bomber of the Tehrik-e-Taliban Pakistan (TTP) attacked outside a police special branch in Islamabad on March23, 2009 and a security official was killed and three were injured(The Daily Times, 24 Mar. 2009).Ten terrorists of TTP had attacked on Manawan Police Training School in Lahore with guns and grenades and eight police recruits and a civilian were killed and 93 were injured(Tanveer, 2009). The suicide bomber of TTP had struck a camp of Frontier Constabulary (FC) in Islamabad on April4, 2009 and killed eight FC personnel and a civilian and 12 were injured (Shakeel, 2009). Tehrik-e-Taliban Pakistan's suicide bomber had blown himself at a Shia gathering in Chakwal on April 5, 2009 and 22 people were killed and 60 people were injured (The Daily Times, 6 Apr. 2009). Nine people were killed including five security personnel and 25 were injured in a suicide attack on May 21, 2009 near a Frontier Corps fort in Jandola (Dawn, 22 May. 2009). The suicide bomber of TTP blew himself near the office of the Inter-Service Intelligence (ISI) in Lahore on May 27, 2009 and 27 people were killed and 326 were injured in the attack. (The Daily Times, 28 May. 2009). The suicide attacker of TTP had killed two police men in Islamabad on June 6, 2009 (The Nation, 7 Jun. 2009). A massive truck bomb blast on the Pearl Continental Hotel in Peshawar on June 9, 2009 and killed 11 people and 60 were injured in the attack (The News International, 10 Jun. 2009). The suicide bomber of TTP had attacked at the Jamia Naeemia Madrassa in Lahore on June 12, 2009 and killed Sunni Barelvi religious leader Moulana Sarfraz Ahmed Naeemi along with six people and five were killed (Dawn, 13 Jun. 2009).

The TTP suicide bomber killed two soldiers when he blew himself near the vehicle of army in Muzaffarabad on June 26, 2009 (The Daily Times, 27 Jun. 2009). A suicide bomber hit his motorcycle into bus carrying the army-run Heavy Mechanical Complex (HMC) employees in Rawalpindi on July 2, 2009 and injured 36 persons (Dawn, 3 Jul. 2009). 16 policemen were killed in Mingora on August 30, 2009 when a suicide bomber of TTP hit the police station (The Daily Times, 31 Aug. 2009). The Taliban militants had killed four school children in Atmankhel of Orakzai Agency on September 8, 2009 (Dawn, 9 Sep. 2009).Taliban suicide bomber attacked the United Nations World Food Programme in Islamabad on October 5, 2009 and killed five people including one Iraqi citizen and injured six persons (Associated Press, 6 Oct. 2009). Nine Taliban militants had attacked on Pakistan Army General Headquarters (GHQ) in Rawalpindi on October 10, 2009 and killed six soldiers and five SSG Commandos (The News International, 11 Oct. 2009). The Taliban militants launched three separate terrorist attacks in Lahore on October 15, 2009 and killed 19 people including 14 police men and injured 41 people. Those attacks were carried out at Federal Investigation Agency (FIA) building, The Manawan Police Training School and Elite Police Academy on Bedian road, Lahore (Dawn, 16 Oct. 2009). The Taliban suicide bomber attacked on the offices of the Special Investigation Unit (SIU) in Peshawar on October 16, 2009 and 15 people were killed including three policemen (The Daily Times, 17 Oct. 
2009). Two Taliban suicide bombers blast themselves in the new campus of International Islamic University Islamabad on October 20, 2009 and killed six students and injured 29 students including 25 female students (The News International, 21 Oct. 2009). The Taliban suicide bomber exploded himself at the police check post near the Pakistan Aeronautical Complex (PAC), Kamra on October 23, 2009 and killed eight persons including two PAF security personnel and 17 were injured. (Dawn, 24 Oct. 2009). The Taliban militant exploded a bomb in Peshawar on October 28, 2009 and killed 118 people and injured 200 people(The Daily Times, 29 Oct. 2009). The Taliban suicide bomber hit the military check post in front of Regional Headquarters of Inter Service Intelligence (ISI), Peshawar on November 13, 2009 and 17 people including 10 military personnel were killed and 60 were injured (Dawn, 14 Nov. 2009). Taliban suicide bomber hit the Pakistan Naval Complex, Islamabad on December 2, 2009 and killed three naval personnel and nine were injured in the attack(The Daily Times, 3 Dec. 2009). The Taliban militants attacked the Friday prayer at the Askari Mosque in Rawalpindi on December 4, 2009 and 40 people including 17 children, an Army Major General, A Brigadier, Two Lieutenant Colonels, A Major and number of soldiers were killed and 86 people were injured(The News International, 5 Dec. 2009). This was nineteen attacks on army and eight incidents near GHQ Rawalpindi. The Taliban militants hit three capital headquarters of Lahore, Quetta and Peshawar on December 7, 2009 and killed 81 people and injured 205 people (Dawn, 8 Dec. 2009). A suicide bomber with a pick-up truck packed with explosives hit gate of the office of InterServices Intelligence (ISI) in Multan on December 8, 2009 and killed 12 people and injured 47 people (The Nation, 9 Dec. 2009). This was fourth times attacks on ISI building in Pakistan. The militants of Taliban had exploded a car bomb in Dera Ghazi Khan on December 15, 2009 and 27 people were killed and 50 were injured in the attack (Dawn, 16 Dec. 2009). The Taliban suicide bomber hit the Muharram Procession in Muzaffarabad, Azad Kashmir on December 27, 2009 and killed 15 people and injured 100 people (The Daily Times, 28 Dec. 2009). The TTP militants hit the Shia Procession in Karachi on December 28, 2009 and killed 42 people and injured 120 people (Dawn, 29 Dec. 2009). The Taliban suicide bomber hit the gathering watching a Volley Bal match in Lakki Marwat on January 1, 2010 and 130 people were killed and 253 were injured (BBC News, 1 Jan. 2010). The Taliban militants fired a rocket into a residential area of Peshawar on February 24, 2010 and four people were killed in the attack (Dawn, 25 Feb. 2010). The Taliban suicide bomber hit his vehicle with building of Anti-Terrorist in Lahore on March 8, 2010 and killed 13 people and injured 60 people (The Nation, 9 Mar. 2010). Two suicide bombers of Taliban hit the military vehicles in a crowded are in Lahore on March 12, 2010 and killed 45 people and injured 100 people (BBC News, 12 Mar. 2010). It was reported that 9 soldiers were also killed in the attacks. Taliban militants attacked a security check post in Peshawar on March 17, 2010 with rockets. Five security personnel were killed (Dawn, 18 Mar. 2010). 5 soldiers were killed with the clash with Taliban on March 26, 2010 in Orakzai Agency (Dawn, 27 Mar. 2010). Taliban militants attacked the Pakistan Army Convoy in North Waziristan on April 23, 2010 and killed 7 soldiers were killed and 16 were injured (BBC News, 23 Apr. 2010). There was a clash between Pakistan Army and Taliban militants in Orakzai Agency on May 10, 2010 and 9 soldiers were killed (BBC News, 10 May. 2010). Taliban had killed two men of accusing spying for US in North Waziristan on May 21, 2010 (Reuters, 21 May. 2010).The Taliban militants had attacked two Ahmadi Mosques in Lahore on May 28, 2010. Two separate attacks were carried out on mosque at Garhi Shahu and Model Town. More than 95 people were killed and 108 were injured in the attacks (Dawn, 29 May. 2010). Three Taliban militants fired the hospital in Lahore on May 31, 2010 and killed 8 people and 40 were injured The Nation, 1 Jun. 2010). Taliban had killed a person in a public execution in football ground during a football match in Miran Shah on June 8, 2010 (BBC News, 8 Jun. 2010). The Taliban tacked and destroyed a NATO Convoy near Islamabad on June 9, 2010 and killed 7 people and injured 4 (BBC News, 9 Jun. 2010). The Taliban militants killed 3 and injured 5 army soldiers in Orakzai Agency on June 21, 2010 (Dawn, 22 Jun. 2010). Two Taliban suicide bombers blast themselves in Shrine of Data Gunj Bakhsh in Lahore on July 1, 2010 and 42 people were killed and 180 
people were injured The Nation, 2 Jul. 2010). Taliban suicide bomber had blown himself in the office of local administrator in the village of Yakaghund on July 9, 2010 and killed 100 people and 120 were injured (BBC News, 9 Jul. 2010). Taliban suicide bomber had targeted a paramilitary police headquarter in Peshawar on August 4, 2010 and killed 5 people and injured 12 others people. The Chief of Frontier Constabulary was also killed (Dawn, 5 Aug.2010). A suicide car-bomber of Taliban hit the police station in Bannu on January 12, 2011 and 17 people were killed and 20 people were injured (BBC News, 12 Jan. 2011). The Taliban suicide attacker had blown himself in a mourning procession of Hazrat Imam Hussain near the Kerbala Gamay Shah in Lahore on January 25, 2011 and 13 people were killed and 70 were injured( The Nation, 26 Jan. 2011). The Taliban exploded in Peshawar on March 9, 2011 and killed 40 people and injured 60 people (Dawn, 10 Mar. 2011). Two Taliban suicide bombers blast themselves in the shrine of Hazrat Sakhi Sarwar in Dera Ghazi Khan on April 3, 2011 and 50 people were killed and 120 people were injured. (The News International, 4 Apr. 2011). Two suicide bomber of Taliban had attacked a paramilitary academy for training young cadets in Charsadda on May 13, 2011 and killed 80 people and 15 were injured (Dawn, 14 May. 2011).

Tehrik-e-Taliban Pakistan (TTP) called it the revenge for the killings of Osama bin Laden. The Taliban attacked Mehran Naval Station, Karachi on May 22, 2011 and killed 9 naval personnel and also destroyed 2 Pakistan P-3C Orion Maritime Surveillance aircraft (Alex, 2011). The Taliban suicide bomber blew himself in a funeral ceremony of a tribal elder who was anti-Taliban on September 15, 2011 in Peshawar and 25 people were killed (The Washington Post, 16 Sep. 2011). The Taliban terrorist exploded a car bomb outside the house of police officer in Karachi on September 19, 2011 and eight people were killed and several were injured (The Express Tribune, 20 Sep. 2011). Taliban attacked the security force convoy in Razmak on November 5, 2011 and two security personnel were killed and three injured (Dawn, 6 Nov. 2011). Taliban had killed 15 Frontier Constabulary soldiers in Orakzai Agency on January 5, 2012. Those were kidnapped and kept in custody for over a year (Dawn, 6 Jan. 2012). Ten soldiers were killed in Upper Orakzai on January 9, 2012 by the Taliban, who were missing in December, 2011 O(The Express Tribune, 10 Jan. 2012). ver a hundred Taliban militants had attacked a police check post in Peshawar on January 12, 2012 and two policemen were killed and eleven were injured (Dawn, 13 Jan. 2012).Again on January 13, 2012, Tehreek-e- Taliban of Pakistan had attacked on police station in Peshawar and killed three police men (Dawn, 14 Jan. 2012). Taliban militants attacked the District Police office in Dera Ismaeel Khan on January 14, 2012 and one police man and three civilians were killed and eight were injured(The Express Tribune, 15 Jan. 2012). Taliban exploded a remote-controlled bomb in Chelum procession of the Shia in Khanpur, Rahim Yar Khan on January 15, 2012 and eight were killed and many were injured (Dawn, 16 Jan. 2012). Three Taliban Suicide Bombers attacked the police Check Post in Peshawar on February24, 2012 and four police men were killed and six were injured . (The Express Tribune, 25 Feb. 2012). The Taliban militants attacked check post of army near Afghan border on March 25, 2012 and three soldiers were killed (Dawn, 26 Mar. 2012). Taliban had killed seven captured Pakistani soldiers on June 25, 2012 (BBC News, 25 Jun. 2012). The Taliban gunmen attacked a military camp in Wazirabad on July 9, 2012 and killed seven soldiers (The Express Tribune, 10 Jul. 2012). Tehreek-e- Taliban of Pakistan militants attacked a police academy in Lahore on July 12, 2012 and killed nine police cadets (The Express Tribune, 13 Jul. 2012). Tehreek-e- Taliban of Pakistan militants attacked on the Kamra Air Base near Attack on August 16, 2012. One security guard and eight militants were killed. TTP claimed that the attack was in revenge for the deaths of Baitullah Masood and Osama bin Laden (Dawn, 17 Aug. 2012). The Taliban militants attacked Pakistani Army post near the Afghan border on August 29, 2012 and killed eight soldiers (BBC News, 29. Aug. 2012). The Taliban had blown a school in Akora Khattak on October 3, 2012 (Dawn, 3 Oct. 2012). The Taliban activists attacked Malala Yousafzai and injured her on October 9, 2012 in Swat (Dawn, 9 Oct. 2012). The Taliban destroyed Government school in the Malka Dher area of Charsadda in KPK on October 9, 2012 (Dawn, 10 Oct. 2012). 
Taliban had blown up Government Primary school at Usmanabad area of Akora Khattak on October 10, 2012 (Dawn, 11 Oct. 2012). More than three hundred Taliban militants attacked the security force check post in Peshawar on October 15, 2012 and killed SP, and other six policemen (Dawn, 16 Oct. 2012). Taliban killed SP, ten police and FC personnel in Peshawar on October 15, 2012 (The News International, 16 Oct. 2012). The Taliban had made acid attack on two girls in Parachinar on November 3, 2012 (CNN, 3 Nov. 2012). The girls were getting education and Taliban were against the female education.The TTP suicide bomber killed Assistant Superintendent of Police Hilal Haider and injured others two on November 7, 2012 in Peshawar (BBC News, 7 Nov. 2012). A Taliban suicide bomber blew at the gate of Pakistan Rangers' Headquarter in Karachi on November 8, 2012. Two ranger personnel were killed and 21 were injured (The News International, 9 Nov. 2012). The Taliban exploded a bomb in Ashoura procession in Dera Ismaeel Khan on November 24, 2012 and 8 people were killed and several were injured in the explosion (Dawn, 25 Nov. 2012). The Taliban suicide bomber blast in Qissa Khawani Bazaar Peshawar on December 22, 2012 and KPK senior minister Bashir Ahmad Bilour and 8 others were killed (The News International, 23 Dec. 2012). The Taliban dozens militants attacked on an electricity plant in Peshawar on April 2, 2013 and 7 people were killed in the attack (Dawn, 3 Apr. 2013). The Taliban exploded a bomb in Swat on April 14, 2013 and killed an Anti-Taliban local leader of Awami National Party (ANP) (The Express Tribune, 15 Apr. 2013). The Taliban had exploded eight bomb explosions in Lahore, Peshawar and Quetta on April 24, 2013 and killed 11 people and 60 were injured (Dawn, 26 Apr. 2013).The Taliban suicide bomber blew himself in crowd in Peshawar on April 29. 2013 and 8 people were killed (Dawn, 30 Apr. 2013). The Taliban suicide bomber blew himself in crowd in Peshawar on April 29. 2013 and 8 people were killed. (The News International, 30 Apr. 2013). A suicide bomber of Taliban blew himself in rally of Jamiat Ulema -e-Islam on May 6, 2013 (The Express Tribune, 7 May. 2013). The Taliban suicide bomber blast at Shia Mosque in Peshawar and killed 15 people on June 20, 2013 (Dawn, 21Jun. 2013). Taliban exploded a bomb in Food Street in Lahore on July 7, 20013 and three people were killed and many were injured (The News International, 8 Jul. 2013). The Taliban exploded a bomb in Lahore on October 10, 2013(The Nation, 11 Oct. 2013). The Taliban suicide bomber blew himself outside the Imambargah in Rawalpindi on December 17, 2013 and killed three people indulging two police men and injured 14 people (Dawn, 18 Dec. 2012).Since 2014, Tehreek-e-Taliban of Pakistan had been weakened by its internal splits and counterterrorism attacks which had been started by Pakistani security forces against Taliban (The News International, 10 Jan. 2015). A car suicide bomber of Tehreek-e-Taliban Pakistan hit the car of Senior Police Officer Choudhry Muhammad Aslam Khan and Khan and others two were killed on January 9, 2014 in Karachi (Dawn, 20 Jan. 2014). Taliban suicide bomber exploded himself in the crowd in Rawalpindi and 13 people including five security personnel were killed and 29 were injured on January 19, 2014 (Dawn, 20 Jan. 2014).

Taliban militants attacked the District Court in Islamabad on March 4, 2014 and 11 people were killed (The Express Tribune, 5 Mar. 2014). The militants of Taliban exploded a bomb in Fruit Market in Islamabad on April 9, 2014 and 24 people were killed (Dawn, 10 Apr. 2014). The Taliban terrorists attacked Jinnah International Airport in Karachi on June 8, 2014 and 30 people were killed. The 10 militants were also killed (The News International, 9 Jun. 2014). The death of the group's longest standing leader Maulana Fazlullah in U.S. drone strike in Kunar, Afghanistan on June 14, 2018, has weakened the Tehreek-e-Taliban of Pakistan.Taliban suicide bomber blew himself near Wagah Border in Lahore and 60 people were killed and 110 were injured on November 2, 2014 (Dawn, 3 Nov. 2014). The militants of Tehreek-e-Taliban of Pakistan had attacked on Army Public School, Peshawar on December 16, 2014 and 142 people including 132 children were killed and several were injured (The Nation, 17 Dec. 2014). The Taliban exploded a bomb near the Imambargah in Rawalpindi on January9, 2015 and eight people were killed (Dawn, 10 Jan. 2015). The Taliban exploded a bomb in Chani Goth, Bahawalpur and one was killed and three were injured on January 13, 2015. (Dawn, 14 Jan. 2015). Tehreek-e-Taliban of 
Pakistan had blast bomb in Shia Mosque in Shekhupura on January 30, 2015 and 53 people were killed (The Nation, 31 Jan. 2015). The Taliban attacked Shia Mosque in Bahawalpur on February 13, 2015 and killed 19 people (Dawn, 14 Feb. 2015). Taliban exploded in Lahore on February 17, 2015 and 8 people were killed and 19 were injured (The News International, 18 Feb. 2015). The Taliban had exploded a bomb in Shia mosque in Rawalpindi on February 18, 2015. 3 people were killed and several were injured in the explosion (The Nation, 19 Feb. 2015). Two Taliban suicide bombers blast in two churches of Christian in Lahore on March 15, 2015 and killed 14 people and 70 were injured (Dawn, 16 Mar. 2015). The Taliban suicide bomber blast himself at the residence of Punjab Home Minister, Shuja Khanzad and killed 14 people including Shuja Khanzada on August 16, 2015(The Nation, 17 Aug. 2015). The Taliban exploded a bomb in Multan on September 13, 2015 and 10 people were killed (Dawn, 14 Sep. 2015). The Taliban militants attacked Pakistan Air Force base in Peshawar on September 18, 2015 and 29 people including an army Captain were killed (The News International, 19 Sep. 2015). The Taliban suicide bomber blast at NADRA office in Mardan on December 29, 2015 and killed 26 people and 56 were injured in bomb blast (Dawn, 30 Dec. 2015). The Taliban exploded a bomb near the polio center in Quetta on January 13, 2016 and 15 people were killed and several were injured (The Express Tribune, 14 Jan. 2016). The suicide bomber had blast himself in the premises of local court in Charsadda on March 8, 2016 and 10 people including three police men were killed and 14 were injured (BBC News, 8 Mar. 2016). The Taliban exploded a bomb in a bus carrying government employees in Peshawar on March 16, 2016 and 17 people were killed and 53 were injured (Dawn, 17 Mar. 2016). The Taliban suicide bomber hit the main entrance of Gulshan-eIqbal Park in Lahore on March 27, 2016 and 74 people were killed and 338 were injured in the attack (The Nation, 28 Mar. 2016). Three Taliban terrorists attacked the police training center in Quetta on October 24, 2016 and two suicide bombers blast themselves and other attacker was killed. 60 people were killed and 190 were injured (The New York Times, 25 Oct. 2016). The Taliban suicide bomber blast himself in the shrine of Shah Noorani in Khuzdar on November 12, 2016 and 52 people were killed and 100 were injured (Dawn, 13 Nov. 2016). The Taliban attacked with grenade on a funeral in Peshawar on November 22, 2016 and 3 FC personnel were killed and 5 others were injured (The News International, 23 Nov. 2016). The Taliban suicide bombers attacked an Army Camp in Mohmand Agency on November 26, 2016 and 2 Frontier Corps (FC) personnel were killed and 14 others were injured (Dawn, 27 Nov. 2016). Taliban killed SAMAA TV Assistant Cameraman Taimoor Khan in Karachi on February 12, 2017 (The Express Tribune, 13 Feb. 2017). The Taliban had blast bombs outside the Punjab Provincial Assembly in Lahore on February 13, 2017 and killed 14 people including DIG and SSP Operations were killed and 87 were injured (Dawn, 14 Feb. 2017). Taliban suicide bomber blew himself in the shrine of Lal Shahbaz Qalandar in Sehwan, Sindh on February 16, 2017 and 88 people were killed and 350 people were injured (The Express Tribune, 17 Feb. 2017). The TTP militants killed 4 Rangers personnel and injured 3 and 10 TTP militants were also killed by the Rangers on April 14, 2017 (Dawn, 15 Apr. 2017). The TTP suicide bomber blast himself in Lahore on July 24, 2017 and 25 people were killed and 53 were injured (The Nation, 25 Jul. 2017). The Taliban exploded a bomb targeting military personnel on August 12, 2017 and 8 soldiers and 7 civilians were killed in the attack (Dawn, 13 Aug. 2017). The Taliban militants opened fire in the hostel of Agricultural training Institute of University on December 1, 2017 and nine students were killed (The Nation, 2 Dec. 2017). A Taliban suicide bomber attacked military camp in Swat on February 3, 2018 and killed 11 soldiers (Dawn, 4 Feb. 2018). The TTP suicide bomber had blast himself near the police check post in Raiwind Lahore on March 14, 2018 and 10 police men were killed (The Express Tribune, 15 Mar. 2018). The Taliban suicide bomber blew himself up near a bus carrying the employees of an Atomic Agency PAEC in Attack on May 3, 2018 (Dawn, 4 May. 2018).The Taliban attacked the Pakistan Army in the Ladha, South Waziristan and killed three soldiers on October 17, 2018 (The Express Tribune, 18 Oct. 2018). The Taliban militants opened fire on FC on South Waziristan on October 19, 2018 and killed two FC personnel (Dawn, 20 Oct. 2018). The Taliban exploded a bomb targeting a vehicle of security 
forces in the Bajaur District and four security personnel were injured on October 29, 2018 (The Nation, 30 Oct. 2018). The Taliban militants attacked the vehicles of army with rockets in North Waziristan on November 18, 2018 (The News International, 19 Nov. 2018). The gunman and suicide bomber of Tehreek-e- Taliban Pakistan attacked and blast in Loralai on January 29, 2019 and 9 people including 8 policemen were killed and 22 were injured in the attack (Dawn, 30 Jan. 2019). The Taliban suicide bomber blast outside the Data Barbar in Lahore on May 8, 2019 and killed 13 people (The Nation, 9 May. 2019). The female suicide bomber of Taliban blast herself in the hospital in Dera Ismaeel Khan on July 21, 2019 and killed seven people (South China Post, 21 Jul. 2019).

\section{Conclusion}

This research indicates that the Tehrik-e-Taliban Pakistan is an umbrella of different key players and terrorist groups. Till his death, Baitullah Mehsud had run Tehreek-e-Taliban network successfully in the Federally Administered Tribal Areas, Khyber Pakhtun Khwa, Sindh and Punjab. The Tehreek-e-Taliban of Pakistan has regularly underwired its links with various worldwide terrorist networks, and internal other Pakistan-based groups that are formally focused on sectarianism. Thus, Tehreek-e-Taliban Pakistan is not only threating the internal security of Pakistan but also disturbing the whole region. With an incursion of assorted clusters and individuals, the Tehrik-e-Taliban has surfaced as an accumulation of fighters hailing from a range of different nationalities, ethnicities and tribes. These nationalities are Pashtuns, Arab, Afghan, Chechen, Uzbek and Punjabi militants. Tehreek-e-Taliban Pakistan (TTP) and Al-Qaeda (AL) are operating collaborated terrorist attacks in Pakistan and Tehreek-e-Taliban Pakistan is main militant organization in Pakistan who is not only challenging the Pakistani state but also fighting against the Law Enforcement Agencies(LEA) and is main facilitator of Al-Qaeda(AL). The Taliban umbrella group is not active in Khyber Pakhtun Khwa but it has strong roots in Punjab and Sind

\section{References}

(2007, December 11). Dawn, Lahore.

(2007, December 24). Dawn, Lahore.

(2007, December 24). The Daily Times, Lahore.

(2007, December 28). Dawn, Lahore.

(2008, February 10). The Nation, Lahore.

(2008, February 12). The Daily Times, Lahore.

(2008, February 5). Dawn, Lahore.

(2008, January 11). Dawn, Lahore.

(2008, January 18). The Daily Times, Lahore.

(2008, March 1). Dawn, Lahore.

(2008, March 5). The News International, Lahore

(2008, May 19). The Daily Times, Lahore.

(2008, September 21). Dawn, Lahore.

(2009, August 10). The Daily Times, Lahore.

(2009, August 31). The Daily Times, Lahore.

(2009, August 6). Dawn, Lahore.

(2009, December 16). Dawn, Lahore.

(2009, December 28 ). The Daily Times, Lahore.

(2009, December 29). Dawn, Lahore.

(2009, December 3). The Daily Times, Lahore.

(2009, December 5). The News International, Lahore.

(2009, December 8). Dawn, Lahore.

(2009, December 9). The Nation, Lahore.

(2009, July 3). Dawn, Lahore. 
(2009, June 10). The News International, Lahore. (2009, June 13). Dawn, Lahore.

(2009, June 27). The Daily Times, Lahore.

(2009, June 7). The Nation, Lahore.

(2009, March 4). Dawn, Lahore.

(2009, May 22). Dawn, Lahore.

(2009, May 28). The Daily Times, Lahore.

(2009, November 14). Dawn, Lahore.

(2009, October 11). The News International, Lahore.

(2009, October 16). Dawn, Lahore.

(2009, October 17). The Daily Times, Lahore.

(2009, October 21). The News International, Lahore.

(2009, October 24). Dawn, Lahore.

(2009, October 29). The Daily Times, Lahore.

(2009, October 6). Associated Press.

(2009, September 9). Dawn, Lahore.

(2010, April 23). BBC News, London.

(2010, August 5). Dawn, Lahore.

(2010, February 25). Dawn, Lahore.

(2010, January 1). BBC News, London.

(2010, January 12). BBC News, London.

(2010, July 2). The Nation, Lahore.

(2010, July 9). BBC News, London.

(2010, June 1). The Nation, Lahore.

(2010, June 22). Dawn, Lahore.

(2010, June 8). BBC News, London.

(2010, June 9). BBC News, London.

(2010, March 12). BBC News, London.

(2010, March 18). Dawn, Lahore.

(2010, March 27). Dawn, Lahore.

(2010, March 9). The Nation, Lahore.

(2010, May 10). BBC News, London.

(2010, May 21). Reuters.

(2010, May 29). Dawn, Lahore.

(2011, April 4). The News International, Lahore.

(2011, January 26). The Nation, Lahore.

(2011, March 10). Dawn, Lahore.

(2011, May 14). Dawn, Lahore.

(2011, November 6). Dawn, Lahore.

(2011, September 16). The Washington Post, Washington, D.C.

(2011, September 20). The Express Tribune, Lahore.

(2012, August 17). Dawn, Lahore.

(2012, August 29). BBC News, London.

(2012, December 18). Dawn, Lahore.

(2012, December 23). The News International, Lahore.

(2012, January 10). The Express Tribune, Lahore.

(2012, January 13). Dawn, Lahore.

(2012, January 15). The Express Tribune, Lahore.

(2012, January 16). Dawn, Lahore.

(2012, January 6). Dawn, Lahore.

(2012, July 10). The Express Tribune, Lahore.

(2012, June 25). BBC News, London. 
(2012, March 26). Dawn, Lahore.

(2012, November 25). Dawn, Lahore.

(2012, November 7). BBC News, London.

(2012, November 9). The News International, Lahore.

(2012, October 10). Dawn, Lahore.

(2012, October 11). Dawn, Lahore.

(2012, October 16). Dawn, Lahore.

(2012, October 16). The News International, Lahore.

(2012, October 3). Dawn, Lahore.

(2013, April 15). The Express Tribune, Lahore.

(2013, April 26). Dawn, Lahore.

(2013, April 3). Dawn, Lahore.

(2013, April 30). Dawn, Lahore.

(2013, February 15). Dawn, Lahore.

(2013, July 8). The News International, Lahore.

(2013, June 21). Dawn, Lahore.

(2013, May 7). The Express Tribune, Lahore.

(2013, November 2). Dawn, Lahore.

(2013, October 11). The Nation, Lahore.

(2014, April 10). Dawn, Lahore.

(2014, December 17). The Nation, Lahore.

(2014, January 10). The News International, Lahore.

(2014, January 20). Dawn, Lahore.

(2014, June 9). The News International, Karachi.

(2014, March 5). The Express Tribune, Lahore.

(2014, November 3). Dawn, Lahore.

(2015, August 17). The Nation, Lahore.

(2015, December 30). Dawn, Lahore.

(2015, February 14). Dawn, Lahore.

(2015, February 18). The News International, Lahore.

(2015, February 19). The Nation, Lahore.

(2015, January 10). Dawn, Lahore.

(2015, January 14). Dawn, Lahore.

(2015, January 31). The Nation, Lahore.

(2015, March 16). Dawn, Lahore.

(2015, September 14). Dawn, Lahore.

(2015, September 19). The News International, Lahore.

(2016, January 14). The Express Tribune, Lahore.

(2016, July 10). The News International, Lahore.

(2016, March 17). Dawn, Lahore.

(2016, March 28). The Nation, Lahore.

(2016, March 8). BBC News, London.

(2016, November 13). Dawn, Lahore.

(2016, November 23). The News International, Lahore.

(2016, November 27). Dawn, Lahore.

(2017, April 15). Dawn, Lahore.

(2017, August 13). Dawn, Lahore.

(2017, December 2). The Nation, Lahore.

(2017, February 14). Dawn, Lahore.

(2017, February 17). The Express Tribune, Lahore.

(2017, July 25). The Nation, Lahore.

(2018, February 4). Dawn, Lahore. 
(2018, February 9). Dawn. , Lahore

(2018, May 4). Dawn, Lahore.

(2018, November 19). The News International, Lahore.

(2018, October 18). The Express Tribune, Lahore.

(2018, October 20). Dawn, Lahore.

(2018, October 31). The Nation, Lahore.

(2019, January 30). Dawn, Lahore.

(2019, May 9). The Nation, Lahore.

8 Killed in Islamabad Bomb Blast. (2008, August 27). The Daily Times, Lahore.

11 killed in Mohmand Suicide Blast. (2008, October 27). The Daily Times, Lahore.

22 killed in suicide attack on Chakwal Imambargah. (2009, April 6). The Daily Times,

Lahore.

3 corps among 5 killed in attack on Malakand University. (2009, March 19). The Daily Times.

Abbas, H.(2017, January 1). A Profile of Tehrik-i-Taliban Pakistan. CTC, West Point,

Alex, R. (2011, May 23). Militant storm naval base in Pakistan. Los Angeles Times, Los

Angeles.

At least 59 die as Militants Storm Police College near Quetta, Pakistan.(2016, October 25).

The New York Times, New York City.

Carlotta, G., Khan, I., Shah, P. \& Taimoor(2009,April 1). Pakistani and Afghan Unify in Face of US influx. The New York Times.

Cop killed in suicide attack on Special Branch Office in Islamabad. (2009, March 24). The Daily Times, Lahore.

Counter Terrorism Department Punjab Police, General Knowledge, Proscribed organizations, p. 27

Death Toll From Pakistan Arms Plant Suicide Rises to 70. (2008, August 27). Bloomberg.

Female Suicide Bomber strikes hospital in Pakistan, killing 9. (2019, July 21). South China Morning Post.

Gunmen kill three policemen in Peshawar. (2012, January 14). Dawn, Lahore.

Harnisch, H. (2009, July 17). Question Mark of South Waziristan: Biography and Analysis of Maulvi Nazir Ahmad. Critical Threats.

Malala Yousafzai to be provided best medical treatment: Zardari. (2012, October 9). Dawn, Lahore.

Mir, A. (2009, March 5). The Swelling Force of Extremism. The News International, Lahore.

Mir, H. (2008, July 21). 8,000 Fighters in FATA Ring Alarm Bells in Islamabad. The News

International, Lahore.

Nine policemen killed in attack claimed by TTP. (2012, July 13). The Express Tribune, Lahore.

Over 10,000 Taliban in FATA: DG ISPR. (2009, September 30). Daily Times, Lahore.

Pakistan Taliban target female students with acid attack.(2012, November 3). CNN.com.

Parlez, J.(2008, August 12). 14 killed in Attack on Pakistani Air Force Bus. The New York Times.

Police HQ attacked in Islamabad. (2008, October9). BBC News.

Raiwind blast: Death toll rises to 10 as investigators call it suicide attack. (2018, March 15).

The Express Tribune, Lahore.

Rana, A.(2009). Taliban Insurgency in Pakistan: A Counter Insurgency Perspective. Conflict and Peace Studies, 2(2), 9-31.

Sana Jamal, S. \& Ahsan, M.(2015). TTP - Analyzing the Network of Terror. International Relations Insights \& Analysis, 6.

Seven Police Killed in Pakistan. (2009, February 7). BBC News.

Shakeel.(2009, April 5). Ten die as suicide hits FC camp in Islamabad. The News International, Lahore.

Six killed in Pishin Girl's Madrassa suicide blast. (2009, March 3). The Daily Times, Lahore. 
Suicide attack on Peshawar police station leaves four dead. (2012, February 25). The Express Tribune, Lahore.

Tanveer. R. (2009, March 31). Lahore Braves Terror. The Daily Times, Lahore.

Tribal Areas under Centralized Control. (2007, December 16). Daily Times, Lahore.

TTP appoints Mufti Noor Wali Mehsud as chief after Fazlullah's killing(2018, June 23). Dawn.

TTP claims responsibility for attack on SAMAA TV van in Karachi. (2017, February 13). The Express Tribune, Lahore.

United States Department of States (2017, July 19). Country Reports on Terrorism 2016 Foreign Terrorist Organizations: Tehrik-e Taliban Pakistan (TTP).

Yusufzai, R. (2008). A who's Who of the Insurgency in Pakistan's North-West Frontier Province: Part One-North and South Waziristan. Terrorism Monitor, 6(18), 1-10. 